\title{
Recent Legislation: Community Property, Homesteads, Persons, Social Welfare
}

TN THE community property field there are significant changes. Civil

Code sections 167 and $168^{1}$ are amended, the former to make the wife's earmings liable for her post-marital debts, the latter to make them liable for debts of the husband when contracted ${ }^{2}$ for necessaries furnished to them or to either of them while they are living together. Both these liabilities are expressly made applicable to previously incurred debts as well as to debts arising subsequent to the amendments. A new section, section $171 \mathrm{~b}$, is added ${ }^{3}$ which exempts the separate property of the wife for a debt (or obligation) secured by hypothecation of commumity property, unless she expressly assents in writing to the liabihty of her estate to such debt (or obligation).

The wife's earnings which, in the absence of agreement to the contrary between husband and wife, are, of course, community property, thus have become available as such, for the first time, to her post-marital creditors. No longer are they to be a species of "spendthrift trust" for the husband, his to spend, but available to neither his nor her post-marital creditors. ${ }^{4}$ This change $\mathrm{m}$ section 167 in practical effect makes a legislative imroad upon the husband's right to manage and control the community property. Hitherto the wife, while entitled to support, has had no right generally to charge the community estate with her contracts unless they were "secured by a pledge or mortgage ... [of community

1 Cal. Stats. 1937, p. 1497, \$\$ 2, 3.

2 Whether contracted by husband or wife.

3 Cal. Stats. 1937, p. 1497, §1.

4 Presumably they always were liable for her pre-marital debts. See Note (1934) 22 CALIF. L. REv. 554, 555. It has been suggested (Legis. (1937) 11 So. CaLIr. I. Rev. 91, 93) that this immumity of the wife's earnings "seems inconceivable" and that, therefore, her earnings might have been liable for her torts and her contracts even without the present statute. To quote from this comment, in speaking of the wife's earnings, "Since not liable for the debts of the husband, it might well be argued that this type of community property is under the management and control of the wife and, as such, should be liable for her debts, including tort and contract." In brief, this theory (unsupported by any case law) is that exemption of this form of community property from the husband's debts deprived him of his control and management of the property and conferred such control upon the wife, with the result that it became liable for her contracts! Aside from the non-sequitur in conconcluding that one forfeits control of property when it is made exempt from liability for debts, this theory seems untenable because of the compelling provisions of the code. By Civil Code section 167 prior to its present amendment, it was unequivocally stated that only with the husband's deliberate assumption of responsibility by pledge or mortgage could any community property be liable for the wife's 
property] executed by the husband." If her husband authorized her to make purchases on credit for non-necessaries, she was his agent, and the resultant debt was, of course, his debt. But if without permission, she made imdependent contracts, the creditor in the absence of the aforementioned pledge or mortgage by the husband, had to look to her separate estate for satisfaction. If no such estate existed, the creditor was without remedy. In consequence, in granting credit to working married women who owned no separate estate the husband's permission was all important.

Instead of directly giving the wife complete control of her earnings as is done in two of the community property states, ${ }^{8}$ section 167 in backhanded fashion gives the California wife practical control in making purchases. It would seem futile for the husband, as comnunity property manager, ${ }^{7}$ now to refuse to permit her to expend her earnings directly. The only result of such refusal would be to push her to credit transactions and the satisfaction of her debt through attachment of her wages, with increased loss to the community. The costs of attachment are substantial.

It does not follow, of course, from the recent changes, that what is purchased on credit by the wife now becomes her separate estate. The "personal" credit of either spouse, i.e., that which rests on other than separate property, belongs to the community, and it follows that that which is acquired through such credit is a community asset. ${ }^{8}$

- Nothing has been done to alter this principle. By her earnings and acquisitions through credit predicated upon earning capacity, the wife still adds to the assets of the community property and not to her separate estate. Now, however, to the extent of her earnings, she may also add

contracts. Moreover, the doctrine of control by the hushand of the marital community is fundamental in our commumity property system. The language of the original code section that "the hushand has the management and control of the community property with like ahsolute power of disposition as he has of his separate estate" laid down a general principle of management by the hushand that has been perpetuated while adding limiting amendments (cf. 1891, 1901, 1917 amendments to 172-172a, Cal. Stats. 1891, p. 425, Cal. Stats, 1901, p. 598, Cal. Stats. 1917, p. 829). Even the new section added in 1927 to define the interests of the husband and wife in the community property (section 161a) reiterated that the spouses held their "present existing and equal interests under the management and control of the husband as is provided in sections 172 and 172a." Italics added.

5 CAL. Civ. Code \$ 167, before the 1937 amendment. See Note (1929) 17 CALIF. L. REv. 265-270.

B Idazo Code (Bohhs-Merrill, 1932) § 31, suhsecs. 913, 914; Nev. Comp. Laws (Hillyer, 1929) §3365 (Complete control of her earnings when using them for the maintenance and care of herself and her family). Texas, in a provision similar to the 1937 amendinent to California Civil Code section 167, makes her earnings liable for her contracts. TEX. CoNIP. STATs. (Vernon, 1936) art. 4623.

7 Which he still is. Sections 172 and 173 making him manager remain unaltered.

8 Moulton v. Moulton (1920) 182 Cal. 185, 187 Pac. 421; Vandervort v. Godfrey (1922) 58 Cal. App. 578, 208 Pac. 1017. 
to the liabilities of the community in defiance of the husband's desires as community manager. ${ }^{9}$

The amendment to section 168 , as stated above, allows those who furnish necessaries to either or both of the spouses (when living together) to obtain payment by attaching the wife's earnings, where previously the section baldly stated, "The earnings of the wife are not liable for the debts of the husband." Just how much of a change this has wrought is uncertain. Debts for such necessaries are, of course, normally ${ }^{10}$ the husband's debt, as he is obligated to support his wife. ${ }^{11}$ As the supreme court had decided that the term "husband's debt" as used in section 168 did not mean merely debts of his separate estate but included all his debts, ${ }^{12}$ the wife's earnings, so long at least as they were coinmunity property, were by virtue of this section and its interpretation beyond the reach of the husband's creditors, including those who furnished necessaries to the family. It was arguable, though doubtful, that, because of the express exemption granted in section 168 , these earnings enjoyed the same immunity even when they became the wife's separate property, by virtue either of release by her husband or by operation of law under section $169 . .^{13}$ Under section 171, however, such of the wife's separate estate as becomes hers other than by ownership before marriage, by gift from someone other than her husband, or by succession or devise, for many years has been made liable for necessaries furnished the husband or wife (or both) while hiving together. Her earnings, when separate estate, fall within the general description of the property thus made liable by section 171 . Therefore, only by construing the specific exemption of section 168 as controlling over the general liability imposed in section 171, could her earnings, when her separate estate, have escaped attachment in satisfaction of debts for necessaries prior to the 1937 change. ${ }^{14}$

Passing reference might be made to the fact that the retroactive aspect of the section imposing liability upon the wife's earnings for her debts, in strict logic might be questioned on constitutional grounds, to

${ }^{8}$ It was occasionally evidenced by the supreme court that it realized and objected to the inequity of the previous situation of the wife being only an asset. This objection probably was responsible for the somewhat problematical decision (from a technical legal standpoint) of Hulsman v. Ireland (1928) 205 Cal. 345, 270 Pac. 948. Cf. Note (1929) 17 Calif. L. Rev. 265.

10 If, through infirmity, he cannot support himself, she must support him (CAI. Civ. CODE ₹ 176); if destitute, even though not infirm, she is responsible for his support under the Aid to the Indigent Act. See Car. Welfare Code § 2576.

11 CaI. Crv. Code \& 174.

12 Street v. Bertolone (1924) 193 Cal. 751, 226 Pac. 913.

13 Making the wife's earnings her separate estate when she lives apart from her husband.

14 Cf. Note (1934) 22 CaLIF. L. Rev. 554, 555. 
the extent that the community estate is still vested in the husband. ${ }^{15}$ The traditional view of the California supreme court has been that retroactive interference with the husband's control of community property violated the due process clause. Such a view has refused to recognize the wife's place in the narital community as sufficient justification for imposing in her interest, himitations on the husband's control that concededly could not be imposed on behalf of a stranger. Thus the 1891 proviso that the husband should not give away the community estate without the wife's consent was held inapplicable to community property already in the husband's hands. ${ }^{16}$ Similarly the requirement added in 1917 that the wife join in instruments purporting to sell, mortgage, etc. community realty was held to be effective only upon after-acquired community ${ }^{17}$ and the testamentary power given the wife in 1923 was restricted to community acquired after that date. ${ }^{18}$

It follows that the imposition of liability on the community earnings of the wife, for her already existing debts, contracted at a time when she had no power without his express action to bind the community property by her contracts, by analogy, might be challenged as an unconstitutional interference with the husband's property right in the community. Exemption privileges are, of course, a matter of grace and their removal involves no constitutional problem. Cutting down or removing altogether the exemption of the wife's community earnings from liability for the husband's debts would be such a case. They always have been his to spend along with the rest of the conmunity property, and he can make no complaint if immunity granted them from his debts be removed for past as well as future debts. The wife, however, has had no control of her earnings and the imposition of liability upon then for her past debts might well be deemed another natter. ${ }^{19}$

The new provision, section $171 \mathrm{~b}$, which exempts the wife's separate estate from liability for debts or obligations secured by hypothecation of conımunity property unless she expressly assents in writing to the liability of her separate estate, probably was intended for situations arising out of the necessity of the wife's signature in transactions under Civil Code section 171.20

15 Query: Since the 1927 amendment does his vested right attach to only onchalf of the cominunity property earned?

18 Estate of Spreckles (1897) 116 Cal. 339, 48 Pac. 228.

17 Roberts v. Wehmeyer (1923) 191 Cal. 601, 218 Pac. 22.

18 McKay v. Lauriston (1928) 204 Cal. 557, 269 Pac. 519.

${ }^{10}$ In brief to the extent of his property right in her community earnings, you are loading the cominunity with another person's debt and in effect retroactively interfering with his control.

${ }^{20}$ Authority for this is inerely the statement of the member of the Legislature who introduced the bill which resulted in the Amendments. 
It is business custom to demand that the wife sign the promissory note as well as the mortgage or deed of trust in connection with which the note is given (and in which she must join ${ }^{21}$ ), and in result, such borrowing by the husband on the strength of community realty has forced the wife into hazarding her separate estate.

There is, of course, no legal requirement that the wife join with the husband in the hypothecating of personal property. The practice of insisting that she sign promissory notes accompanying such pledges is much less universal. The new section, however, covers indebtedness involving the encumbering of both realty and personalty.

A situation analogous to the one corrected, arises out of the requirement of the wife's signature in conveyances of community realty. It has been held that her signature carries with it liability of the wife's separate estate for breach of warranties impliedly included in the deed. ${ }^{22}$ This situation remains unadjusted. This is the more to be regretted in that the change which is made in the new section is intended to correct the results of the business custom of demanding the wife's signature on the promissory note which accompanies the mortgage in which the wife is required by law to join. The situation which is left untouched arises not fron business custon but from the legal requirement itself that the wife inust join in conveyances of community realty. In brief, in order that her husband may lawfully convey coinmunity realty of which he is the business manager, she must run the risk of involving her separate estate. ${ }^{23}$ It would seem clear that an expansion of new section $171 \mathrm{~b}$ is called for.

\section{HOMESTEADS}

Amendment of Civil Code sections 1269a-1269c on alienation of the homestead almost certainly effects no change of law. ${ }^{24}$ When one of the spouses becomes insane or incompetent, authority now is given specifcally to the court to order an exchange of the homestead, an authority which no doubt was included in the already existing power to order the homestead to be sold and conveyed. Curiously enough in sections dealing with community property, under similar circumstances, i.e., insanity of one of the spouses, the word "exchange," while added in 1933 to Civil Code section $172 \mathrm{~b}$ authorizing the petition to the court, still is omitted in the section (172d) empowering the court to act on the petition.

Two deletions in section 663 of the Probate Code, relative to the survivorship of the homestead, merely remove meaningless words ${ }^{25}$ that

21 CaL. Crv. Code $\$ 171 \mathrm{~b}$.

22 Platner v. Vincent (1924) 194 Cal. 436, 229 Pac. 24.

23 A clause negativing the warranty implied from the word "grant" could, of course, be added to prevent this.

24 Cal. Stats. 1937, p. 174.

25 The section formerly provided that a lomestead which had been selected from the separate property of the decedent without lis or her consent vested on 
should have been omitted on enactment of the Probate Code. Such "tidying up" of the code provisions is excellent practice.

Section 1238 of the Civil Code has been amended ${ }^{26}$ to state that a homestead may be declared upon property held by the spouses as tenants in common or in joint tenancy. ${ }^{27} \mathrm{As}$ stated in the last issue of this Revieve, if this statement be construed as restricted to property held by the spouses inter se as jomt tenants or as tenants in common, it is merely a codification of existing case law..$^{28}$ If construed as also permitting the homesteading of the tenancy in common or joint tenancy interest of a spouse (or the spouses) with third parties, whether or not it has worked a change in law depends upen whether a provision added in 1929 be construed as having already authorized such a homestead..$^{20}$

\section{MARRIAGE, DIVORCE, AND SEPARATION}

In the act relating to the care and control of venereal diseases, ${ }^{30}$ etc., section 13 provides that any person who, knowing that he has a venereal infection, "marries or has sexual intercourse" is guilty of a misdemeanor. No one could object to the principle mherent in this addition to our listed penal offenses. How effective it will prove as a means of preventing the spread of this terrible scourge through sexual intercourse is another question.

The technique which has been employed in Scandinavian countries with such conspicuous success, of free diagnosis and free treatment of all venereal infections is a basic procedure long overdue in this as in other American states. Unfortunately such a basic procedure comes in conflict with "vested interests" of private medical practitioners and only with the pressure of much stronger and more determined public opinion than has so far been mobilized, will it be achieved. Meantime such a modest requirement as that of medical certification from all who apply for a marriage license, of freedom from venereal infection, encounters no such obstacle and would be at least a step in the right direction. ${ }^{31}$ It may

death in his or her heirs. Cal. Stats. 1931, p. 626. Since the wife's estate may not be hoinesteaded without her consent, the words "or her" in each case were without effect and now are omitted. Cal. Stats. 1937, p. 479.

26 Cal. Stats. 1937, p. 1690.

27 Subject to the rule that the wife's estate may never be hoinesteaded without her consent as provided in section 1239.

${ }^{28}$ Swan v. Walden (1909) 156 Cal. 195, 103 Pac. 931. Lucci v. United Credit \& Collection Co. (1934) 220 Cal. 492, 31 P. (2d) 369.

${ }^{29}$ See for further discussion, comment on the creation of homesteads and its incidents, Note (1938) 26 CALIF. L. REv. 241, 244.

30 Cal. Stats. 1937, pp. 2248, 2251.

31 Wisconsin now requires this from both applicants. See Wis. Stats. 1937, p. 484. Illinois has a similar requirement. InI. STATE BAR Stats. (1937) c. 89, §6a. 
be regretted that this was not legislated. It can scarcely be questioned that such a requirement would be a desirable complement to the present penal proviso.

\section{INCOME TAX EXEMPTION TO SPOUSE PAYING ALIMONY}

Section 10 of the State Income Tax Act ${ }^{32}$ now permits a $\$ 2,500$ exemption, not only to the head of a family and to a married person living with husband or wife, but also "in case of a person contributing to the support of a former husband or wife by order of a court of competent jurisdiction." Apparently this means that a man who pays any alimony to a divorced wife is entitled to the full exemption. ${ }^{33}$

The amendment makes no provision for the separated husband who is paying alimony to his wife under a so-called "separate maintenance" order. Such a person is still married and so is not supporting a "former" spouse. The tax regulations do not classify him as a "head of a family"34 and obviously he is not a "married person living with his wife." Ergo, he is not entitled to the $\$ 2,500$ exemption even though he is paying at the order of the court the full cost of the support of his separated wife. This situation seems the more unjust in that the wife who has a cause for divorce may, at her option, separate from her husband and seek permanent maintenance rather than divorce and alimony.

Alimony orders vary from very small monthly amounts to those affording very generous support. It seems a most questionable policy to allow full exemption to an ex-husband who may be contributing, for example, only ten dollars a month or less to the support of an ex-wife.

The only other change made in this field (new section 137.5 Civil $\mathrm{Code}^{35}$ ) is a "creditors bill," the creditor in this instance being the attorney. Hereafter the court may in its discretion make attorney's fees allowed in prosecution or defense of divorce and separation suits, payable in whole or in part directly to the attorney. This may be deemed by some to be a legislative judgment upon the integrity of this special group of clients and by others just another instance of the evolution of the practice of law from a profession to that of a busmess. In any event, it would seem a reasonable provision.

32 Cal. Stats. 1937 , p. 1843.

33 Since a Lusband is not entitled to alimony from lis divorced wife, as section 139 of the Civil Code lias not been aunended to permit tlis, in the present state of the law there cannot be a person contributing to the support of a former husband by order of a court of competent jurisdiction.

34 Regulations, Personal Inconie Tax Act (1935) Sec. 10, Art. 10.2.

35 Cal. Stats. 1937, p. 479. 


\section{INFANTS-PARENT AND CHILD}

\section{(Other than the Welfare Code provisions)}

Section 350 of the Vehicle Code, which deals with applications for driving licenses of minors, has been amended in several particulars. ${ }^{36}$

First, there is a new definition of the term "minor." It now excludes "persons of eighteen years or over who have been married." This, in terms at least, is not restricted to persons who are married at the time of application. ${ }^{37}$

Second, all applications for minors' licenses now must be verified.

Third, while previously if the minor did not have two custodial parents (i.e. live in the normal family home) anyone having custody of him, whether parent, guardian, employer or other person, could sign this application for a license. Now if he has a parent, only he may sign; in the absence of such parent, the guardian, if any, must sigu, and only if there is neither a parent nor guardian may any other custodial person sign.

Fourth, on the signing and verifying of the application by either the adult spouse of a married minor who is under eighteen years of age or the parents of either spouse, ${ }^{38}$ or on filing by the married minor under eighteen of ability to respond in damages in accordance with section 414 (Vehicle Code), a license may be issued.

Fifth, with the written permission of the parents, parent or other person authorized to sign the minor's application, a license now may be issued without such signature, merely on proof of ability by the minor to respond in damages. Acquiescing in this situation, moreover, does not of itself impose liability under section 352 upon the consenting parent, guardian or other adult person in question, for the negligence of the minor licensee.

Section 257 relative to licenses issued to minors under sixteen now provides that the department shall impose ${ }^{\text {so }}$ (formerly may impose) appropriate restrictions upon such license.

\section{INFANTS' CONTRACTS}

Section 10112 of the Insurance Code ${ }^{40}$ has been amended. It previously stated that minors shall not, by reason only of such minority, be

36 Cal. Stats. 1937, p. 1596.

37 Whether the exclusion would be held to include a person over eighteen years of age whose marriage had been annulled may be questioned. Technically, on annulment, the marriage in the eyes of the law never has taken place. It is completely wiped off the record.

38 That is, of either the minor or the minor's spouse.

39 Cal. Stats. 1937, p. 1593.

40 Cal. Stats. 1935, p. 637. 
deemed incompetent to contract for life or disability insurance or for annuities and required written consent of a parent or guardian to such contracts when the minor is under sixteen.

The amendment provides that when personal liability for assessment is involved there shall be written assumption by a parent or guardian of such liability, in consideration of the issuance of the contract to the minor. It is specified that this assumption of liability may be limited to the period of minority. 41

\section{PARENT AND CHILD: ADOPTION}

Section 224 of the Civil Code has been amended ${ }^{42}$ to substitute a reference to section 413 of the Code of Civil Procedure for the erroneous reference to section 413 of the Civil Code.

A new section, Civil Code 227,43 makes the first statutory provision for the setting aside of an adoption decree at the request of the adopting parent. The general principle of caveat emptor has been fairly rigidly applied in adoption situations on the assumption that he who selects a child and formally makes it his own inust, like a natural parent, hazard that the child may prove a disappointment. The new code section makes an exception that would seem completely reasonable, especially in the light of the practice on the part of the child-placing agencies of encouraging the adoption of very young infants. When an adopted child manifests signs of being feebleminded, epileptic or insane and this is a "result of conditions prior to the adoption," then, provided the petitioner had no knowledge or notice of such conditions, he may now have the decree of adoption set aside. Presumably, the clause "is a result of conditions prior to the adoption" is included merely to prevent the nullification of an adoption decree because of a mental condition brought on by an accident, illness or other circumstance after the child has been made a member of the family, and is not intended to require actual medical proof that the mental condition in question is a "result of prior conditions."

The privilege of setting aside an adoption ordinarily must be exercised within five years after the entering of the decree. Those persons, however, who adopted children more than five years before this enactment are privileged to act within the year following the effective date of the new section, provided the unfortunate mental condition became evident within five years of the adoption.

\section{WELFARE AND INSTITUTIONS CODE}

Code sections and general laws relating to dependent, defective and handicapped groups now have been regrouped and reclassified in code

41 Cal. Stats. 1937, p. 2031.

42 Cal. Stats. 1937, p. 786.

43 Cal. Stats. 1937, p. 786. 
form as the Welfare and Institutions Code. ${ }^{44}$ This new code contains seven divisions which include inter alia the Juvenile Court Act, the State Aid to Needy Children Act, the Old Age Assistance Act, the Act for the Relief of the Needy Blind, the Relief of Indigents' Act, as well as the various acts dealing with the commitment and treatment of the various types of mental incompetents.

The State Department of Social Welfare's Executive Board has been reorganized. ${ }^{45}$ The former board of seven composed of an executive director and six associates appointed by the governor, is replaced by a board of seven similarly appointed, which, however, will not include the director but instead will appoint and employ an executive officer to serve as Secretary of the Board and as Director of the Department of Social Welfare. It is stipulated that appointments to the Board shall be made because of "interest and leadership in social welfare activities without regard to political or religious affiliations or profession or occupation," and that the Director shall be selected on the basis of "training, demon. strated ability, experience, and leadership in organized social welfare administration." 46

Four divisions within the Department, in addition to others to be added as they are needed, for (1) Adult and Family Welfare, (2) Aid to the Needy Aged, (3) Aid to the Needy Blind, and (4) Child Welfare have been created by amendment to the code. ${ }^{47}$ Each division is to be headed by a chief and is to have assigned to it the functions of the Department portinent to the name of the division.

The powers and duties of the State Relief Commission and State Relief Admmistrator are expressly transferred to and vested in the Department. ${ }^{48}$

In each of the divisions of the code which deal with state aided services, it is repeated that the Social Welfare Board shall make rules and regulations for the admimistration of the services (aid to the needy aged,

44 Cal. Stats. 1937 , p. 1005.

45 Cat. Welfare Code $\S \S 101,105$.

46 Ibid. $\S \S 101,106$.

47 Ibid. \& 111 .

48 It was questioned whether this was a constitutional transfer in view of the fact that the former bodies were created by constitutional amendment. The Attorney General ruled against the constitutionahity, and the State Relief Commission has continued to function independently. Meantime the seven members of the Social Welfare Board have been added to the State Relief Commission, thus giving practical identity of directorates to the two bodies. (The Relief Commission has nine members, the seven Social Welfare Board members, the latter board's director, and one additional member.)

In view of the great influence of the opinions of the Attorney General's office upon the welfare activities of the state, it, is to be regretted that these opinions are not available in published form. 
to dependent children, to the needy blind) and that these rules and rgulations shall be binding upon the counties.9.$^{49}$ it also stipulated that the county "must grant aid" when directed to do so by the Board and "must withdraw aid" on command of the central body.

All these provisions have been prompted by the grants-in-aid of the federal Social Security Act, in which it is stipulated that federal funds shall be available to a state, only under conditions in the state of central responsibility for effective administration of the services receiving federal funds..$^{50}$

In the divisions dealing with care of the indigent, aid to the aged and aid to the blind, provisos have been inserted which recognize the separated wife's actual residence for relief purposes, in lieu of a domicile derived from that of her husband.51 Other amendatory changes have been made in most of the major acts included in the code, the more important of which will be noted for each of the acts.

\section{OLD AGE ASSISTANCE}

Numerous changes have been made in the Old Age Assistance Law, all, with the exception of the administrative changes, "liberabzing" ones,

49 Cal. Welfare Code $\$ \$ 1560,2140,3075$.

5042 U.S.C.A. $\$ \S 302,602,703,1202$. The federal government for some months has been demanding that California set up "minimum qualification standards" for all persons hereafter appoimted by the counties to do the "social service" work of investigating the eligibility of applicants for the state and federal-aided assistance services. It would seem from Welfare Code sections $1560,2140,3075$, referred to above, and section $114 \mathrm{~b}$ that the setting up of such standards is well within the power conferred upon the Board of Social Welfare. Certain of the chartered counties challenge the constitutional propriety of such action on the score that they are constitutionally authorized to set up the quabifications of their deputies and employees (CAL. CoNST., Art. XI, $\$ \S 7 I / 2,8 T / 2$ ). Conceding that county welfare workers are employees and not officers, it might seem at first glance that the state could not prescribe personnel standards for them for any purpose. However, the charter sections of the constitution, as the supreme court of this state has held, must be interpreted in the hight of their purpose, which is to give chartered counties local autonomy in regard to what might be called "county affairs." Reuter v. Board of Supervisors (1934) 220 Cal. 314, 325, 30 P. (2d) 417, 422.

Clearly im the provision required for the needy aged, dependent children, and the blind, we do not have a purely "local affair," but a state affair (cf. San Francisco v. Collins (1932) 216 Cal. 187, 191, 192, 13 P. (2d) 912, 914). While of constitutional necessity, the chartered counties must be allowed a free hand in the selection of and in setting qualifications for their employees in the carrying out of their local affairs, it does not follow that this same liberty is theirs in the selection of and fixing of qualifications of employees to carry out a state purpose. It is quite possible, and it has been so held by our appellate courts, that an officer may serve in a dual capacity. Thus a county officer, in performing certam city functions, may be a city officer (Madary v. City of Fresno (1912) 20 Cal. App. 91, 94, 128 Pac. 340, 342). Similarly, a city employee may have state functions to perform and in that capacity be a state officer, and be paid out of the county treasury (Boss v. Lewis (1917) 33 Cal. App. 792, 166 Pac. 843). A county employee performing state functions must meet state requirements.

51 CaL. Welfare Code $\$ \$ 2161,2554,3042.10$. 
i.e., calculated to make "aid to the aged" more easily obtained, obtained by more persons and in larger amounts and without liability of the recipient's property for repayment even on the death of the recipient. One change, in legal theory at least, is basic: The aged applicant's eligibility for aid hitherto has been determmed on the basis of whether he had or had not a spouse or adult child able to maintain him adequately. Now, as has always been the case in "Aid to the Needy Blind," 52 the question asked is whether as a fact he is being adequately maintained by such relative regardless of the existing ability of the latter to provide.53

If the applicant is not adequately provided for, he must be given the grant in aid. The authorities may then proceed against the responsible relatives for recoupment if the latter are able to maintain the old person and have failed to do so. 54

Previously, the law apparently contemplated that the aged person who was neglected by his family should proceed against them himself to force support. ${ }^{55}$ Ordinary "poor relief" was, of course, due him from the county meantime.

The change is a codification of good social service practice, is a technique which had already been adopted in the "Aid to Needy Blind Act," and seems an eminently more civilized approach to the problem. The authorities are in a far better position to extract funds from the unwilling family than is the dependent old person. To withhold from the applicant actually in need because of the indecent neglect of his family, the preferred type of assistance which this aid spells, ${ }^{56}$ visits punishment upon the wrong person.

Other changes in old age issistance are inter alia: (1) a minimum

52 This has been the case since the original 1929 Act. Cal. Stats. 1929, p. 910.

53 CaI. Welfare Code $\$ 2060$.

5£ CAL. Welfare CODE $\$ 2224$. The evolution of the "responsible relative" list is as follows: At the time of the original State Aid to the Aged Act (Cal. Stats. 1929, p. 914) the aged applicant was eligible only if he had "no children or other person able to support him and responsible under the laws of this state." This referred to the list of responsible relatives in the General Aid to the Indigent Act which at that date (1929) included (sec.6) husband, wife, adult. child, father, mother, brother, sister, grandchildren, grandparents. (This list in the Indigent Act was reduced by Cal. Stats, 1933, pp. 2005, 2006, § 2, to spouse, parent or adult child). The Aid to the Aged Act was anended by Cal. Stats. 1931, pp. 1310, 1311, to unake the listed responsible relatives include only husband, wife, parent or child, and by Cal. Stats. 1935 , pp. 1767,1768 , to elininate from the list the word "parent". As very few of the aged could have had living parents, this last change had little practical result.

55 See Cal. Stats. 1935, pp. 1767, 1768.

56 This Old Age Assistance is "preferred" in the sense of being larger in anount, and in addition it always has been regarded as "above" ordinary relief. This is reflected in the specific statement in a 1937 annendment (CAL. WeLFArE CODE $\S 2009$ ) that "no person receiving aid under this chapter shall be deemed a pauper by reason thereof." 
standard amount of aid now is absolutely required instead of impliedly directed as previously. ${ }^{57}$

(2) In estimating the applicant's income to determine the grant which he is eligible to receive, the following items are to be disregarded up to a total of $\$ 15$ inonthly: 58

"(a) Income from the applicant's labor or service; or rent from the premises owned and occupied by applicants;

"(b) The value of foodstuffs produced by the applicant for the use of himself or his family;

"(c) The value of firewood or water produced on the premises of the applicant or given to him by another;

"(d) The value of gifts other than regular contributions by relatives legally responsible under this chapter."

(3) Aid is authorized to applicants who live on a month to month basis in boarding homes or other institutions which do not receive any public support. (Previously aid was not granted unless the old person lived in a private household.)

(4) The section relative to proof of the age of the applicant is modified, ${ }^{69}$ (a) so as to obligate the acceptance as definite proof of age, of any one of the various documents which formerly merely had to be given consideration and also (b) so as to require the acceptance of affidavits without even the two limitations previously included, which formerly read that (i) "such affidavit shall not be accepted to establish proof of age until all reasonable efforts to produce inore substantial documentary evidence of the applicant's age have failed" and (ii) "Where the departinent deems that an affidavit does not present satisfactory evidence of applicant's age, it may require a further affidavit of inore conclusive proof." $" 00$

(5) It is provided that in computing personal property owned by the applicant, insurance policies of five years standing not exceeding in toto $\$ 1000$, shall be disregarded. ${ }^{11}$

(6) The proviso that aid may be paid for the benefit of an incompetent old person "to a responsible person" is amended by adding the words "acceptable to the recipient" and a clause prohibiting payment of any

57 This is a mere codification in mandatory form of the 1935 proviso which read, "... it is the intent and purpose of this law to allow each ... applicant ... who is not im receipt of board and lodging ... nor of any income from other sources whatsoever, the sum of ... [\$35] per month." Cal. Stats. 1935, pp. 1767, 1769.

E8 Cal. Welfare Code $\S 2020$.

59 Ibid. $\$ 2162$.

60 Ibid. $\$ 2162$, as originally enacted.

61 Ibid. $\$ 2163$. 
part of the aid in the form of "merchandise orders for food, rent or otherwise." $" 12$

(7) The section permitting the rejected applicant an appeal to the State Department of Social Welfare is amplified and clarified. ${ }^{63}$

(8) The section which had made the aid granted a debt due from the recipient to the state and county, to be satisfied out of such of his property, if any, as was not exempt from execution, is repealed. ${ }^{04}$

(9) (a) All existing liens (in favor of the county) upon realty owned by recipients of aid, such liens having been acquired under previous provisions of the law which authorized them as security for reimbirsement of aid granted, on discontinuance of aid or on death of the recipient, are released.

(b) The sections permitting the county to acquire such liens are repealed. ${ }^{65}$

(10) On removal of a recipient to another county, aid through the original county must be continued for a period of a year (i.e. until he acquires legal residence in the second county); also, necessary hospital or inedical care during this year inust be furnished by the new county of residence and the county of original residence must pay the cost thereof. ${ }^{.0}$

(11) Investigation of applications must be completed within ninety days unless an extension of time is granted for "good cause" by the supervisors and the extension is approved by the State Department of Social Welfare. ${ }^{67}$

Space does not pernit detailed comment on all these "other changes." Some, specifically, 1, 3, 7, 10,11, and the first half of 6 , seem to correct obvious defects in the earlier law and to be not debatable. The second half of 6 (requiring money payments) rnay work well as a general principle, but will prevent the welfare worker from guaranteeing food and shelter when dealing with the occasional intemperate old person who periodically squanders his whole grant. It would seem a wiser policy for the protection of sucl a recipient to permit some exercise of judgment by the welfare authorities. One, 4 , seems indefensible, as it is defimitely open to the objection that it facilitates fraudulent imposition upon the public funds. In several, 5, 8, 9, the influence of the Townsend Planners is all too evident. It is to be feared that provisions like these inevitably invite such public reaction as that embodied in the recent Ohio bill in whicl bitter and degrading consequences are attached to the receipt

62 Ibid. \$2183.

63 Ibid. \& 2182.

64 Ibid. $\$ 2224$, as originally enacted.

$65 \mathrm{Ibid}$. $\S \S 2225,2226,2227$, as originally enacted.

68 Ibid. $\$ 2200$.

67 Ibid. $\$ 2181$. 
of general assistance. ${ }^{69}$ All these three, 5, 8, 9, invite the question whether, in view of the many relief problems whicl still are inadequately met, there is propriety in spending public moneys on "assisting needy aged" without the riglit to recoup these expenditures from the estate of the recipient. Why should this estate be passed on to heirs or devisees instead of reimbursing the state to provide funds for other needy causes?

Finally, one, the second inentioned, which directs the disregarding of certain forms of income, seems open to the serious adverse criticism, that it is grossly unfair. ${ }^{69}$

Under this new section an old person who is able to work may earn up to $\$ 15$ a month and still be entitled to receive the full $\$ 35$ grant. $^{\text {.o }}$ In brief, he may live at a $\$ 50$ a month standard. An old person, on the other hand, who is frail of health or for any other reason is unable to earn, must hive at the $\$ 35$ a month standard. Again, an old person who has a kindly disposed friend of means who gives him $\$ 15$ a month may receive the full $\$ 35$ a month grant. He too may live at a $\$ 50$ a month standard. But, if instead of a kindly friend he has only a devoted, though not affluent, son who can and does give liin $\$ 15$ a month, he can only receive $\$ 20$ in aid! He must live at a $\$ 35$ a month standard.

\section{AID TO THE NEEDY BLIND}

One administrative change,,$^{71}$ vitally important in preventing fraudulent claims, is the requirement that proof of blimdness now unust be established by the written medical testimony of a duly licensed and practicing physician skilled in diseases of the eye. Previously any medical practitioner could verify the applicant's claim.

As in the case of the aid to the aged, aid to the "needy blind" now must be an arbitrary minimum amount per montl and not as formerly, maintenance up to a specified maxinum. ${ }^{72}$ In addition, and again as in the case of the aged, various types of actual income may not be counted

68 Such as repeated publication and posting of their names as paupers. House Birl No. $740, \$ 10$, passed by both houses but vetoed.

69 Combined with one of the other changes it may and does in actual practice produce grotesque results. $E$.g. If a private plilanthropic home provides gratuitous room and board for an aged inmate appraised at, for example, $\$ 25$ a month, this being a gift from a person "other than a responsible relative," $\$ 15$ of this is disregarded. The old person is rated as having $\$ 10$ income and thus entitled to $\$ 25$ a month aid to be spent for such solaces as tobacco and other and perhaps more dubious sundries.

70 This encouraging of the aged to enter the active labor market is at marked variance with the national old age insurance program, in which the annuity is forfeited for the month during which the old person is employed.

71 Cal. Welfare Code $\$ 3083$. See former section 5 of the Aid to the Needy Blind Act, as amended Cal. Stats. 1931, pp. 1892, 1894.

72 CaL. Welfare Code $\$ 3084$. 
in determining what the blind applicant's income is. In the case of the blind, however, the income amount that must be disregarded is $\$ 33 \%$ per month instead of the $\$ 15$ allowed the aged, and the income which must be disregarded includes every ordinary source of income except that provided him by his responsible relatives. ${ }^{73}$ There now must be given to the blind applicant who has an income of not more than $\$ 400$ a year, a grant of $\$ 50$ a month (formerly not in excess of $\$ 50$ a month), unless the income which he has is provided by a responsible relative, i.e. spouse, parent, or adult child, in which case aid is reduced by the amount of this income. (Until this year grandchildren and grandparents also were "responsible relatives.") 74

There is no provision for recoupment of these generous grants from the estate of the blind person aided. It may be passed on to heirs and devisees free of any obligation. It seems difficult indeed to justify sucli a situation.

As in the case of the aged, the law thus creates a preferred class of recipients, i.e., those who liave either property or kind and affluent friends or relatives (other than the immediate family), and discriminates against the impecunious blind who are aided only by their children. Tlius, a blind person who has inherited stocks and bonds which yield him $\$ 33 \mathrm{~T} / 3$ a month may draw $\$ 50$ a month in aid and live in comparative comfort as compared with the blind person who has no income at all and who receives the identical grant. Verily, "To him that hath more shall be given" is the spirit of both our aid to the aged and our aid to the blind!

\section{AID TO DEPENDENT CHILDREN}

In contrast to the provision for the aged and the blind is that which is made for dependent children. ${ }^{75}$ No one has ever suggested a scientific

${ }^{3}$ Ibid. subsec. (a)-(f).

$74 \mathrm{Ibid} . \$ 3088$, as originally enacted.

75 Ibid. $\$ 1522$. The history of the aid to needy children (Chapter 1, Part II of the Welfare Code) is most confusing. First, Chapter 1, Part II, of the Welfare Code in re "Needy Children" becaune effective May 25, 1937, with the enactment of the code itself. Then two bills, one amendatory of this chapter (and in the event that no Welfare Code was passed anendatory of the Political Code), and one intended as a replacement of the Welfare Code provisions for needy children, were passed and approved by the Governor, becoming chapters 390 and 389 respectively. Chapter 390 by its terms became effective June 14 . Chapter 389 , replacing altogether the original code's provision for needy children and the amendinents thereof, was to become effective September 1.

Due to the fact that chapter 389 was filed with the Secretary of State afler the filing of the act chaptered as section 390, 389 became operative September 1, 1937, and effected a repeal of the later numbered chapter, 390, and of the original code.

Section $\mathbf{1 5 0 6}$ of the original Welfare Code in defining the classes of children ehigible for state aid, repeated the 1935 Political Code proviso that children deprived of parental support or care by the continued absence or mental incapacity of the parent and who are hiving with the other parent or a listed relative (sce former 
basis for the theory that proper support of an old person costs twice as much as that of a growing child. Nevertheless, the State of California appraises an appropriate standard of living for the needy child at $\$ 25$ a month, in contrast to the $\$ 50$ a month standard approved for the aged! Well may one understand the inplications in the statement recently made by the New York Commissioner of Public Welfare ${ }^{76}$ in comparing the provision made for dependent children with that afforded by most state old age assistance laws. Said Commissioner Adie, "Of course, I realize that the children under sixteen have no lobby!"

It is pleasant to be able to report that the 1937 Legislature, however more liberal in dealing with the adult groups, at least has improved the situation of the children. The age limit at which assistance to needy children must stop has been raised from sixteen to eighteen years and the amount of outside monthly support which renders a child ineligible to any aid has been raised from $\$ 20$ to $\$ 25 ; 7$

Provisions now are included for cases of change of residence sinilar to those made for continued aid to aged persons who move into another county. ${ }^{78}$

Specific rules are laid down for determining on a practical basis the "residence" of a child for purposes of this type of aid. ${ }^{79}$

\section{JUVENILE COURT}

The most significant change in the Juvemile Court Law is found in the amended section 825 of the new Welfare Code ${ }^{80}$ which replaces the clause "no person under the age of eighteen years at the time... of the alleged offence... shall be prosecuted for crime until the matter has first been submitted to the juvenile court" by the words "No court shall have jurisdiction to try the case of any person under the age of eighteen... unless the matter has been first submitted to the juvenile court." To one

CAI. Por. Cone \$ 2290) were eligible for aid. That proviso apparently had been ruled unconstitutional by the Attorney General's office and had remained a dead letter proviso and accordingly was deleted by chapter 389 .

${ }^{76}$ In addressing the Conference of State Directors of Public Welfare during the annual meeting of the American Public Welfare Association, Washington, D.C., December, 1937.

77 CAI. WeLfare Code $\$ \S 1522,1523$.

78 Ibid. $\$ 1527$. See supra note 66.

$79 \mathrm{Ibid}$. $\$ 1526$. It is the residence of the father unless he has abandoned the child or has been deprived of its custody, then the mother's, with similar limitations, then the person who has its legal or actual custody, etc., the residence of the wife meaning her actual residence and not her husband's residence if she lives apart from him.

80 Former section $4 d$ of the Juvenile Court Act was codified in the original section 825 and in effect until August 27, 1937, when the aunendment in question became operative. 
unfamiliar with the case law history of this section of the Juvenile Court Act it might appear that in the new phrasing the Legislature had substituted Tweedledee for Tweedledum. This is, however, far from being the case. The former section was early construed as (1) in no way intruding upon the jurisdiction of the court to try a minor for crime, and (2) as modified and limited by a subsequent procedural section in the Juvenile Court Act, which directed lower court justices when it "was suggested or appeared" that a person charged with crime had been under the age of eighteen at the time of the alleged commission, to transfer the case to the Juvemile Court for consideration. ${ }^{81}$ If, therefore, a minor who was below the stipulated age allowed the prosecution to proceed to the point of conviction and sentence without raising the question of age, his sentence stood despite the fact that he had had no Juvenile Court hearing. ${ }^{82}$ In addition an early case ${ }^{83}$ denied habeas corpus relief when a magistrate defied the mandate of the section and refused to transfer a boy to the Juvenile Court even though he established his age as appropriate for reference to the Juvenile Court and requested a transfer. The Justice in this case stated that the boy could raise the question of his age when he reached the Superior Court, although the Juvenile Court Act put no specific obligation on a Superior Court judge to transfer the case but merely on the Justice of a court other than the Superior Court. Despite, however this lack of specific direction to transfer, cases have ruled that reference of the case to the Juvenile Court was necessary if the fact of appropriate age appeared at any time before the imposition of sentence. ${ }^{84}$ This ruling now has been codified by section 833 of the Welfare Code as passed and reiterated by amendment to section 826 .

These changes are involved in denying jurisdiction to the Superior Court under the circumstances stipulated in section 825: (1) If a boy under eighteen at the time of committing an offence now is prosecuted, convicted and sentenced, the proceedings are void $a b$ initio instead of valid and unassailable as hitherto. (2) If during trial in the Superior Court, the fact is revealed that the accused was under eighteen years at the date of the alleged offence, and the case is referred to the Juvenile Court (im accordance with previous practice and present statutory requirement) no question of jeopardy now can arise. Since there is complete

81 People v. Oxnam (1915) 170 Cal. 211, 149 Pac. 165; In re Bastiani (1927)

81 Cal. App. 294, 253 Pac. 951; People v. Luzovich (1932) 127 Cal. App. 465, 16 P. (2d) 144.

82 In re Tom (1911) 17 Cal. App. 678, 121 Pac. 294; People v. Tossey (1927)

85 Cal. App. 435, 259 Pac. 488 . See also cases cited stipra note 81.

83 In re Northon (1917) 35 Cal. App. 369, 169 Pac. 1051.

84 People v. Tossey, supra note 82. 
lack of jurisdiction under such circumstances, the matter stands before the law as though no trial had been initiated..$^{85}$

\section{SEVERING PARENTAL CONTROL}

By amendnent to section 701 of the Welfare Code $^{86}$ a child may now be declared permanently "free from the custody and control of his parents" for the added reason of moral depravity on their part. 87

Other amendnients to the Juvenile Court Act provide (1) that notice of hearing by the Juvenile Court shall be served by registered mail on "parents, guardians or other custodians" who are neither in nor resident in the county and the registered mail receipt filed by the Probation Officer as acknowledgment of such notice; ${ }^{88}$ (2) that the date on which the annual report of the Probation Committee is to be filed be changed from "before December 1st" to "within 15 days after December 31st"; 89 (3) that the probation officer shall make and keep a record in writing (not to be available to the public except on approval of the Probation Officer or the Judge of the Juvenile Court) of each case investigated after request to the District Attorney for the drawing of a petition that a child be made a ward of court, whether or not such petition is actually drawn; ${ }^{80}$ (4) that recoupnent of county expenditures for the support and maintenance of wards of court may be had at any tine from property of the minor or the parent or guardian responsible for his support, whether or not a reimbursement order ever has been made or revoked; ${ }^{21}$ (5) that

85 It might have been deemed perhaps, under the previous state of law, that objections on jeopardy grounds were impliedly waived on transfer to the Juvenile Court. Since, however, the minor under eighteen never has had any option in regard to such transfer, this was not at all certain. (Juvenile Court Act $\S 6$ ).

86 Juvenile Court Act $\S 15$.

87 Grounds for declarimg wards of court of a year's standing "free from parental custody" now include the following conduct on the part of the parents-abandonment, neglect or cruel treatment, babitual intemperance or moral depravity, and, in the discretion of the court, also conviction of felony, adultery, feeblemindedness, and insanity.

The use throughout section 701 of the plural term "parents" instead of the terms "parent or parents" of the old Juvenile Court Act ( $\$ 15)$ gives the impression of substantive change throughout section 701. Since, however, section 13 of the Welfare Code plainly states that tbe "plural includes the singular and the singular includes the plural," and section 2 indicates a definite intention to work no change of law, no change of law has been effected. It is perhaps unfortunate that the singular term "parent" was not einployed. It would have been equally inclusive (as the "singular mcludes the plural"), is a more familiar technique, and in this instance would perhaps have been less confusing.

88 CaL. Welfare Code $\$ 726$.

89 Ibid. $\$ 643$.

$90 \mathrm{Ibid}$ \$ $\$ 38$. Such written record formerly was required only of cases actually brought before the court.

91 Ibid. \$ 868.10. 
the court may require medical investigation of the need of the minor (concerning whom a petition has been filed) for medical or surgical care and may order such care when needed; ${ }^{92}(6)$ that when a minor has been the subject of a Juvenile Court petition, based on his destitution, (whether or not the child has been declared a ward of court), transfer of the case to a county of new residence may be made only after the minor has resided for the period of one year in the latter county. ${ }^{93}$

Barbara Nachtrieb Armstrong. 